\title{
THE STUDY OF PHYSICAL PROCESSES AND THE OPTIMIZATION OF THE COMPOSITION OF THE RADIATION-SHIELD LAYER OF THE PRODUCT PKN-1A
}

\author{
Y.V. Rudychev ${ }^{1,2 *}$ S.I. Prokhorets ${ }^{1}$, M.A. Khazhmuradov ${ }^{1}$ \\ ${ }^{1}$ National Science Center "Kharkiv Institute of Physics and Technology", 61108 Kharkiv, Ukraine; \\ 2 V.N. Karazin Kharkiv National University, Kharkiv, Ukraine
}

(Received July 7 2020)

The work is devoted to the analysis of the transportation features of isotopic fast neutrons sources from the point of view of the used radiation-shield materials and their compositions. A three-dimensional model of the portable container of the packaging set PKN-1A was developed, and neutron irradiation of the container was simulated under conditions of transportation of the neutron source IBN-8-5. The equivalent dose rate (EDR) values on the surface of containers with different composition of the radiation-shield material are calculated. Experimental studies of the EDR attenuation of neutron radiation from isotopic sources of fast neutrons for samples of various radiation-shield material compositions have been carried out. The results of mathematical modeling are in good agreement with experimental data.

PACS: 28.41.Qb, 28.41.Ak, 28.41.Fr, 28.31.Te,24.10.Lx, 29.30.Kv

\section{INTRODUCTION}

Analysis of the features of transport of isotopic sources of fast neutrons, from the point of view of used radiation-shielding materials and their compositions, demonstrates that in order to protect against neutron radiation is widely used concretes of different composition, water, earth ground, and various poly-
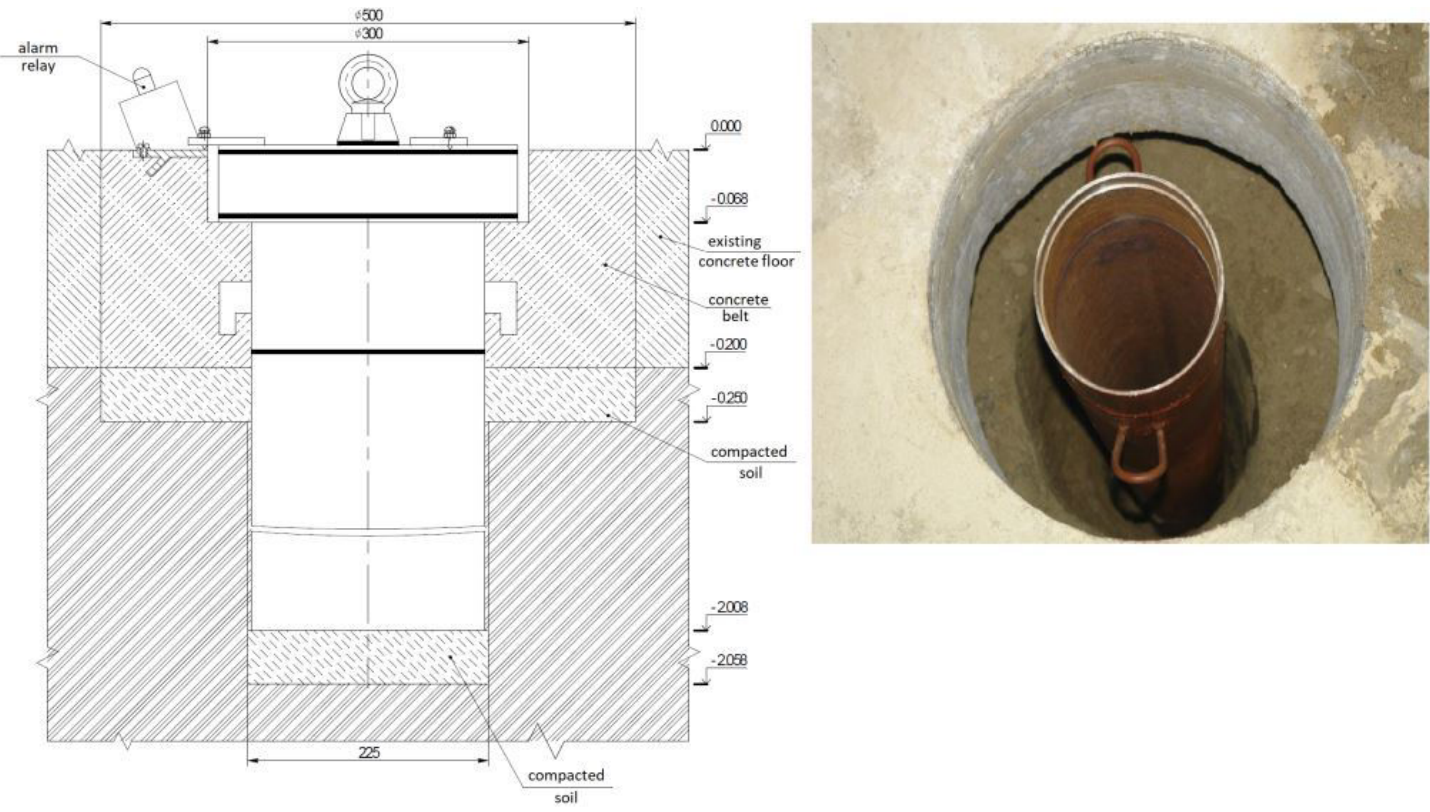

Fig.1. Scheme and general view of the stationary storage system of neutron sources mer materials, having in its composition the hydrogen atoms. The use of water, concrete, soil as protection against neutrons is possible in stationary storage of radiation sources. Scheme and general view of a stationary neutron source storage system at the Institute of Nuclear Physics, Novosibirsk, Russian Federation is presented at Fig.1. 
In Ukraine and other CIS countries development of the mobile vehicles for radiation shielding from neutrons (containers, packaging systems) received the bulk of attention. In modern practice high pressure borated polyethylene and WEP (Water Extended Polyester) are applied as the radiationshielding materials during transport of fast neutron sources. Series of transport containers produced by Hopewell Designs, Inc., USA is presented at Fig.2.

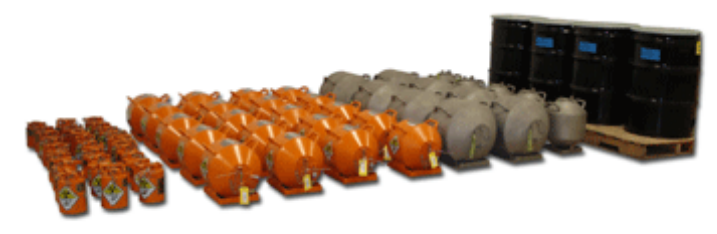

Fig.2. Series of transport containers SC1315N ... $S C 5158 N$

The use of such materials in the manufacture of equipment for domestic transportation of neutron sources is difficult because of their high cost, lack of domestic production of such materials, technological difficulties in their use in the actual production and insufficient durability. The Russian and the domestic production of the mobile vehicles for radiation shielding from neutrons (containers, packaging systems) are widely used radiationshielding compounds based on paraffin. Examples of Russian and Ukrainian packaging systems are shown at Figs.3a and 3b, respectively.

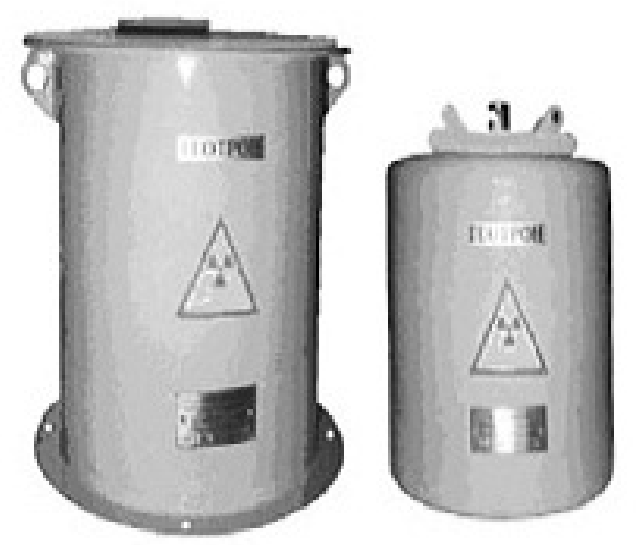

Fig.3a. Set packing UKTIIA-380, OPEN JOINT STOCK COMPANY "GEOTRON", Tyumen, Russia

Radiation-protective materials must provide and keep the ability to attenuation of ionizing radiation (in this case the neutron radiation) for the operating temperatures up to $+70^{\circ} \mathrm{C}$.

However, at temperatures below this threshold $\left(\right.$ at $\left.+50^{\circ} \mathrm{C}\right)$ paraffin, which has a complex structure of a number of saturated hydrocarbons, has started melting under the effect of high temperature.

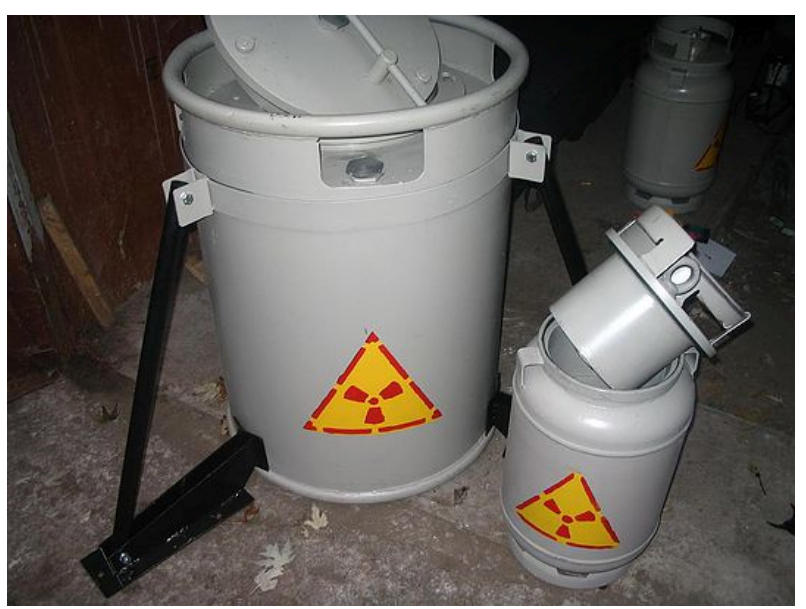

Fig.3b. Set packing PKN-1A, KIEV CENTER OF ENGINEERING TECHNOLOGIES "ATOMBUDPROEKT" Kiev, Ukraine

This causes to a change in homogeneity by volume. Therefore this can involve to a transformation in the radiation-shielding properties of this material. The aim of this work is to study radiation-shielding compounds based on paraffin, their ability to keep homogeneity over the entire operating temperature range, the simulation and experimental study of equivalent dose of neutron radiation on models and prototypes.

\section{MODELING TECHNIQUE}

The radiation isotope source in the shipping container was simulated using the Monte Carlo method using the well-known and most verified MCNP program [1]. For this purpose, the three-dimensional model of the packaging PKN-1A was designed, this model corresponds to the geometric parameters of PKN-1A of the Kiev Center of Engineering Technology "ATOMBUDPROEKT" [2].

Since the radiation doses on the surface of the complex packaging is not significant, the calculations were performed only for the transport container. After the test calculations and based on our experience in solving similar problems [3], it was found that the technical elements such as handles, fastening systems, screw connections and etc. significantly slow down calculation times. Therefore the simplified model of the transport container has been used for the study, as shown at Fig.4 (portable container model).

The following scheme was used for the irradiation simulation: Into the three-dimensional model of the environment (air at $20^{\circ} \mathrm{C}$ in Fig.5 is denoted in blue) was placed isotropic neutron source with spectral characteristics corresponding to the type of NBI source with the possibility of changes in intensity (see Fig.5. It's indicated in yellow). 


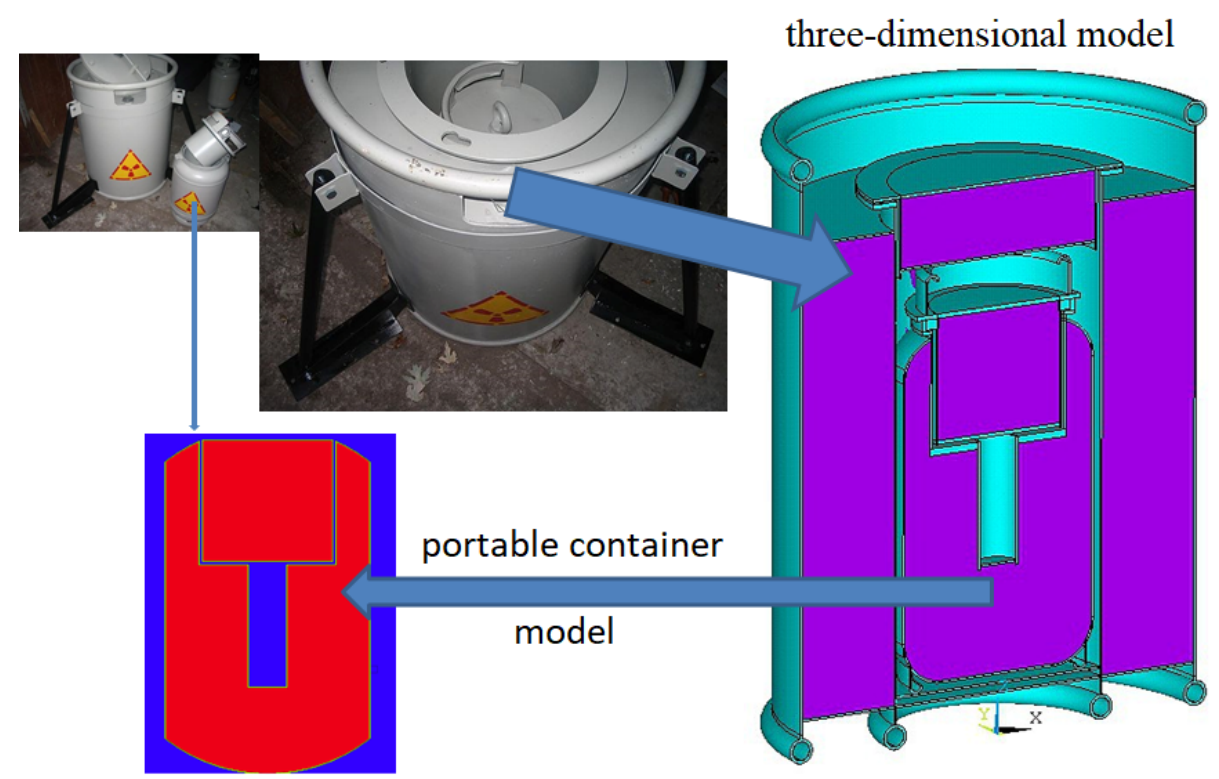

Fig.4. Three-dimensional model of the packaging PKN-1A

This source is located in a portable container made of steel. The container is filled with radiationshielding layer of the material with the ability to change its chemical and isotopic composition (see Fig.5. It's indicated in red). Monte-Carlo simulation scheme of portable container irradiation by isotopic radiation source is shown in Fig.5. The statistical sampling of irradiation source spectrum was obtained according work [4]. Result of Monte Carlo simulation of this spectrum is shown at Fig.6.

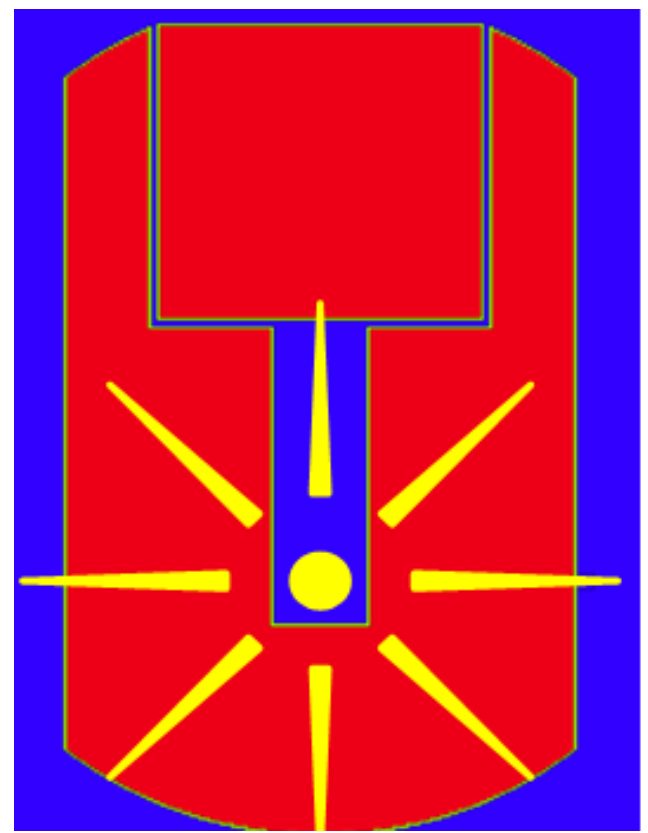

Fig.5. Monte Carlo simulation scheme of portable container irradiation by isotopic radiation source

Kiev Center of Engineering Technology "ATOMBUDPROEKT" produces a set of packaging PKN$1 \mathrm{~A}$ designed for mobile transportation of neutron sources IBN-8-4 type. The source intensity of such source is $5 \times 10^{6} \mathrm{n} / \mathrm{s}$ in the solid angle $4 \pi$.

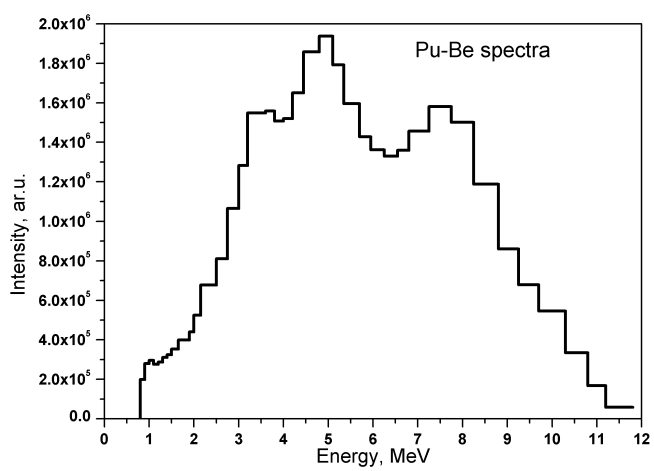

Fig.6. Fast neutron spectrum for Pu-Be source simulations

To ensure the homogeneity of the radiation-shielding material in a temperature range up to $+70^{\circ} \mathrm{C}$, the company PKCHP "OST" proposed to use instead of paraffin composite material $50 \%$ boric acid + $50 \%$ paraffin (patent N UA 98578 U.) According to GOST 16327-88 maximum equivalent dose rate (EDR) of neutron radiation on the surface should not exceed 2,000 mSv/h. For the packaging PKN-1A with neutron source-IBN 8-4 type this condition is satisfied.

However, packaging type UKTA-380 are designed for mobile transportation of sources with an intensity of up to $1 \times 10^{7} \mathrm{n} / \mathrm{s}$, which corresponds to the intensity of 8-5 IBN-source and allows a wider range of applying of such container. According to the above method we simulated irradiation of portable container by the IBN-8-5 type neutron source with an intensity of $1 \times 10^{7} \mathrm{n} / \mathrm{s}$. As a material for the radiationshielding layer of portable container were taken: pure 
paraffin; a mixture of boric acid and paraffin in composition $95 / 5$ and 50/50 mass percent respectively. As a result of the simulation were obtained equiva- lent dose rate (EDR) on the surface of the portable container. The values of EDR data are shown in Table 1.

Table 1. Values of equivalent dose rate of portable container on the surface for various materials of radiation-shielding layer

\begin{tabular}{|l|l|c|c|}
\hline & Pure paraffin & $\begin{array}{c}95 \% \text { paraffin } \\
+5 \% \text { boric acid }\end{array}$ & $\begin{array}{c}50 \% \text { paraffin } \\
+50 \% \text { boric acid }\end{array}$ \\
\hline EDR on the surface, $\mathrm{mSv} / \mathrm{h}$ & 1867 & 1047 & 2182 \\
\hline
\end{tabular}

The simulation results show that when we used as radiation-shielding material layer pure paraffin or a mixture of $95 \%$ paraffin $+5 \%$ boric acid, we achieved the necessary radiation protection conditions. Furthermore a mixture of paraffin and boric acid provides 1.78 times better radiation shielding characteristics.

However, pure paraffin and paraffin-boric acid mixture does not provide material homogeneity in the temperature range up to $+70^{\circ} \mathrm{C}$, since the material structure changes after the melting temperature is reached. On the other hand mixture composition of $50 \%$ paraffin $+50 \%$ boric acid provides homogeneity in the temperature range, due to the higher melting temperature. However, the radiationshielding properties of this material do not comply with GOST 16327-88, since the EDR on the surface of the container is by $9.1 \%$ higher, than the maximum permissible for this source intensity.

In connection with the mentioned above, for a given geometry of the container we must choose a radiation-shielding material which parameters satisfy its homogeneity and the radiation protection requirements.

\section{ANALYSIS OF RADIATION-SHIELDING LAYER FOR PORTABLE CONTAINER}

The effectiveness of radiation-shielding layer is determined by absorption or cross-sections of radiation neutron capture, in this case the reaction $(n, \gamma)$ and $(\mathrm{n}, \alpha)$. Due to the fact, that the values of these crosssections vary significantly depending on the neutron energy, therefore an important factor in the effectiveness of radiation-shielding layer are processes neutron energy change. These processes are determined by the elastic and inelastic scattering or reactions $\left(n, n_{0}\right)$ $\left(\mathrm{n}, \mathrm{n}^{\prime}\right)$ respectively. Note, that since hydrogen and carbon have a small atomic numbers, even by elastic interactions $\left(n, n_{0}\right)$ neutrons lose much of their energy for every act of collision, so these elements are an effective neutron moderator and carbon also has a probability of inelastic reactions $\left(n, n^{\prime}\right)$. Analysis of cross-sections makes it possible to evaluate the effectiveness of radiation-shielding properties of the given materials.
Hydrogen, which is part of the paraffin, effectively moderates neutrons and the boron in the composition of boric acid absorbs thermal and epithermal neutrons. Effective is the homogeneous mixture of $95 \%$ paraffin and $5 \%$ boric acid, unfortunately, it is not practically feasible from the view of the composition homogeneity, since it has a low melting temperature. When we have the mixture of $50 \%$ paraffin and $50 \%$ boric acid this material reduces the effectiveness of neutron moderation, because for carbon and oxygen in elastic interactions the amount of transferred energy from neutron is a 12 and 16 times smaller than the energy for hydrogen, so this composition is slightly less effective than the pure paraffin. To increase the effectiveness of radiation shielding we decided to add in our material the element with a large cross section of neutron interactions, such as lead (Fig.7).

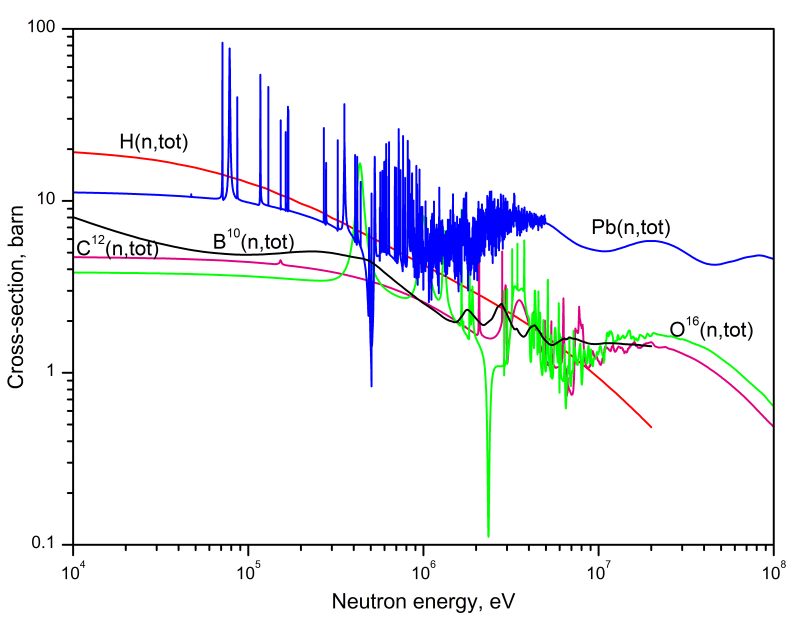

Fig. 7. The total cross-section for the interaction of neutrons with some elements

For fast neutrons in hydrogen, which is part of the paraffin, capture cross section is rather small (Fig.8). Therefore, by adding elements of lead, we obtain an additional mechanism of multi-scattering in elastic interaction, and additional $(\mathrm{n}, \gamma)$ reaction which have higher cross-section than the $(n, \gamma)$ reaction of hydrogen. In other words, neutrons, passing through paraffin, interact with lead atoms and absorbed by the $(n, \gamma)$ reactions or due to the scattering, changed di- 
rection and ultimately moderated by hydrogen atoms and absorbed by boron atoms. As a result of the foregoing, it can be concluded that for small thicknesses the most effective radiation-shielding material is a composition of $50 \%$ paraffin $45 \%$ boric acid and $5 \%$ lead, by increasing the thickness of the radiationshielding layer, the lead influence is reduced because the paraffin layer thickness is enough for effective neutron moderation and their following absorption. Based on the above analysis for different materials of radiation-shielding layer we simulated neutron irradiation of portable container kit packaging PKN-1A, by the plutonium-beryllium neutron source IBN-8-5 type. The source intensity was $1 \times 10^{7}$ neutrons per second in a solid angle of $4 \pi$.

As a result of the simulation were obtained equivalent dose rates EDR on the surface of the portable container. The values of EDR data are shown in Table 2 .

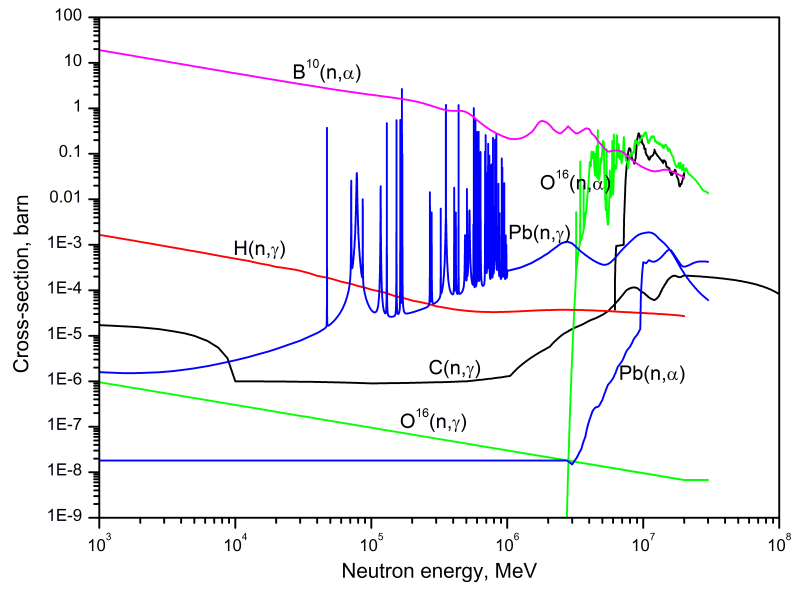

Fig.8. The capture cross section for the interaction of neutrons with some elements

Table 2. Values of EDR of portable container on the surface for various materials of radiation-shielding layer

\begin{tabular}{|c|c|c|c|c|c|}
\hline paraffin & $\begin{array}{c}95 \% \text { paraffin } \\
+5 \% \text { boric } \\
\text { acid }\end{array}$ & $\begin{array}{c}50 \% \text { paraffin } \\
+50 \% \text { boric } \\
\text { acid }\end{array}$ & $\begin{array}{c}50 \% \text { paraffin } \\
+45 \% \text { boric } \\
\text { acid } \\
+5 \% \text { lead }\end{array}$ & $\begin{array}{c}50 \% \text { paraffin } \\
+45 \% \text { boric } \\
\text { acid } \\
+5 \% \text { iron }\end{array}$ \\
\hline $\begin{array}{c}\text { EDR on the } \\
\text { surface, } \mathrm{mSv} / \mathrm{h}\end{array}$ & 1867 & 1047 & 2182 & 1346 & 1560.6 \\
\hline
\end{tabular}

The simulation results completely agrees with the above analysis. Considering the melting point, the most effective is a mixture of $50 \%$ paraffin $+45 \%$ boric acid $+5 \%$ lead.

\section{EXPERIMENTAL VERIFICATION OF THE EFFECTIVENESS OF RADIATION-SHIELDING MATERIALS}

Radiation shielding efficiency for given radiationshielding materials was measured at National Science Center "Institute of Metrology". Namely, they studied the attenuation ratio of neutrons irradiation from fast neutrons source type IBN-9 for the three samples. Sample N1 - paraffin item consist of two bars (pure paraffin), $(60 \times 60 \times 80) \mathrm{mm}^{3}$ sizes and $160 \mathrm{~mm}$ in total thickness, named as $1 \mathrm{~A}$ and 1B. Sample N2 - the item consist of the two bars of paraffin, with a special adding (paraffin 50\% + boric acid $50 \%),(60 \times 60 \times 80) \mathrm{mm}^{3}$ sizes and a total thickness of $160 \mathrm{~mm}$, named as $2 \mathrm{~A}$ and $2 \mathrm{~B}$. Sample $\mathrm{N} 3$ - the item of the two bars with a special paraffin adding (dark color (paraffin $50 \%+$ boric acid $45 \%$ + lead $5 \%))$ with a size of $(60 \times 60 \times 80) \mathrm{mm}^{3}$ and a total thickness of $160 \mathrm{~mm}$, named as $3 \mathrm{~A}$ and $3 \mathrm{~B}$. The scheme of experimental studies is shown in Fig.9.

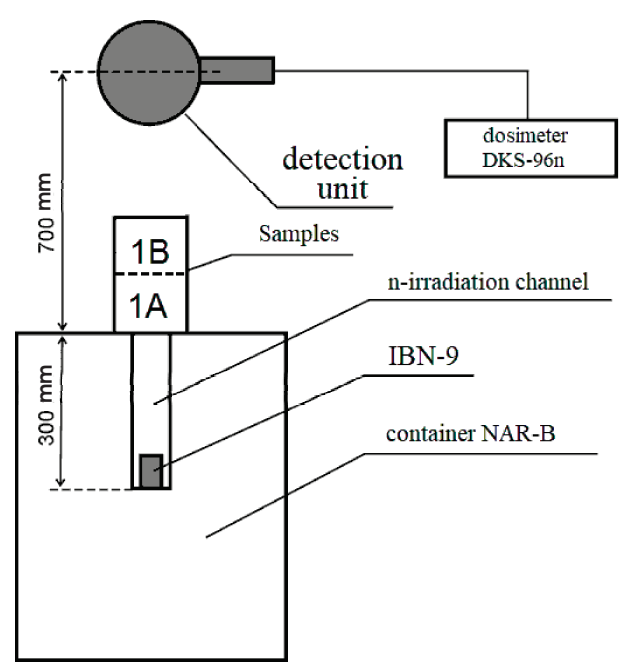

Fig.9. The scheme of experimental studies

Measurement of ambient equivalent dose of neutron irradiation was made by using dosimeter DKS-96n with a statistical error of the measurement result is equal to or less than $4 \%$. The attenuation ratios are: 9.47 for the sample N1; 9.69 for sample N2 and 10.16 for sample N3 respectively. 


\section{COMPARISON OF SIMULATION RESULTS WITH EXPERIMENT.}

To compare the simulation results with experimental data the solid-state three-dimensional model is created similar to the scheme of the experiment (Fig.10). The sample is presented to the model in pink, neutron radiation channel and the environment in blue, container NAR-B yellow cross radiation source and dose detection area is square. In the simulation, when filling NAR-B container used pure paraffin.

Since the simulation is carried out under ideal conditions, we assume that the background is 0 , and subtract background by modeling is not necessary, in addition the efficiency of detection of the detecting device by modeling is $100 \%$. Therefore the attenuation coefficients depend on the material properties (in this case, materials are homogeneous) also ones depend on source spectrum discretization, in this case the sampling intervals is 40 (according to [4]) Table 3 shows the results of a comparison of experimental measurements and modeling.

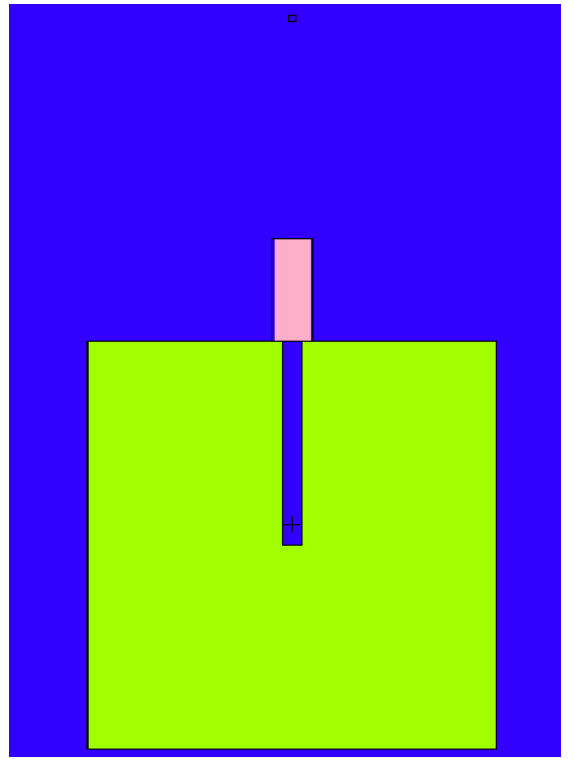

Fig.10. The three-dimensional model is similar to the experimental scheme

Table 3. Comparison of experimental measurements and modeling

\begin{tabular}{|c|c|c|c|c|c|c|}
\hline \multirow[t]{2}{*}{ Samples } & \multicolumn{3}{|c|}{ Experimental measurement } & \multicolumn{3}{|c|}{ Simulation } \\
\hline & $\begin{array}{l}\text { Open } \\
\text { source }\end{array}$ & sample & $\begin{array}{l}\text { Attenuation } \\
\text { ratio }\end{array}$ & $\begin{array}{l}\text { Open } \\
\text { source }\end{array}$ & sample & $\begin{array}{l}\text { Attenuation } \\
\text { ratio }\end{array}$ \\
\hline Sample N1 (pure paraffin) & \multirow[t]{3}{*}{28.56} & 3.01 & 9.47 & \multirow[t]{3}{*}{28.581} & 3.32 & 8.62 \\
\hline $\begin{array}{c}\text { Sample N2 } \\
\text { (paraffin } 50 \%+\text { boric acid } 50 \% \text { ) }\end{array}$ & & 2.95 & 9.69 & & 3.36 & 8.5 \\
\hline $\begin{array}{l}\text { Sample N3 (paraffin 50\%+ } \\
\text { boric acid } 45 \%+\text { lead } 5 \% \text { ) }\end{array}$ & & 2.81 & 10.16 & & 2.31 & 12.37 \\
\hline
\end{tabular}

The simulation results confirm the previously made assumptions; experimental data also confirm the effectiveness of the new material composition. There is a good agreement between the simulation and experiment. The difference between the simulation and experiment is 9,12 , and $17 \%$ for samples N1, N2, N3 respectively. These errors are related to the heterogeneity of the material, not the full identity of the real spectrum of the neutron radiation source and the spectrum used in the simulation. Model of a heterogeneous filling material was built to take into account the effect of the heterogeneity of the mixture. Due to the fact that we do not have reliable data on particle size and structure of the mixture confirmed by microscopic studies, the following assumptions were used in our simulation: This model consist of the powder particles of lead (red), surrounded by pieces of boric acid (yellow) and filled by paraffin (blue color), the shape of all the elements has been selected as cube. Particle sizes were chosen as follows. We know that lead was in powder PS-1 class, so the size of the lead was chosen as $25 \mu \mathrm{m}$ - this is the maximum size, since according to GOST $99 \%$ of the powder of this class spilled out through a sieve with a $25 \mu \mathrm{m}$ cell. On the other hand, we know the mass percent of components in the mixture, then, based on the structure of this model, we obtain the size of boric acid pieces is 103.6 microns, and the size of the cube with paraffin is $145.7 \mu \mathrm{m}$ (Fig.11). As a result, during simulation was used the material dimensions of $(60 \times 60 \times 180) \mathrm{mm}^{3}$ consisting of $146,136,850$ cubic cells, as shown in Fig.11. Similarly we created heterogeneous model for lead-free mixture, in this case the cell size of boric acid was $107.3 \mu \mathrm{m}$ and the cell size with boric acid and paraffin was the same as a last time $145.7 \mu \mathrm{m}$. The simulation results are shown in Table 4. 
Table 4. The simulation results of heterogeneous model

\begin{tabular}{|c|c|c|c|}
\hline Samples & Experiment & Simulation (homogeneous) & Simulation (heterogeneous) \\
\hline & Attenuation ratio & Attenuation ratio & Attenuation ratio \\
\hline $\begin{array}{c}\text { Sample N1 (pure paraffin) } \\
\text { Sample N2 (paraffin 50\% } \\
+ \text { boric acid 50\%) }\end{array}$ & 9.47 & 8.62 & 8.65 \\
\hline $\begin{array}{c}\text { Sample N3 (paraffin 50\% } \\
+ \text { boric acid 45\% } \\
+ \text { lead 5\%) }\end{array}$ & 10.16 & 8.50 & 8.18 \\
\hline
\end{tabular}

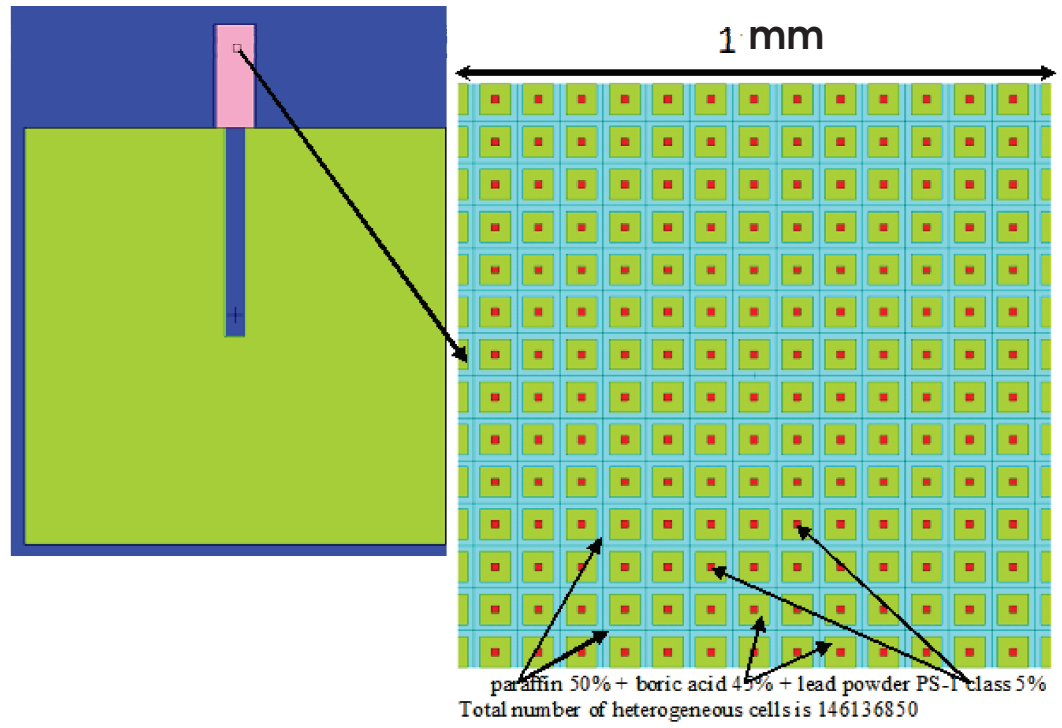

Fig.11. Scheme and general view of the stationary storage system of neutron sources

Due to the fact that the size of modeling elements and the structure may be different from the actual mixture and size of lead powder piece was selected as large as possible. Therefore, to improve the reliability it is better to use the average value of the attenuation coefficients between homogeneous and heterogeneous structures. For material composition: paraffin $50 \%+$ boric acid $45 \%+$ lead $5 \%$ we get $(12.37+$ $8.18) / 2=10.275$, therefore difference from the attenuation coefficient obtained in the experiment is about $1.1 \%$, which is less than the experimental error. Thus, experimental results are in good agreement with simulation results and confirms the earlier assumption that the material composition: paraffin $50 \%+$ boric acid $45 \%+$ lead $5 \%$ satisfies the requirements for homogeneity of the radiation-shielding layer because it has higher melting temperature compared to the paraffin and satisfies radiation protection requirements because it has a higher neutron attenuation coefficient than paraffin.

\section{CONCLUSIONS}

The analysis of the features of transportation of isotopic sources of fast neutrons from the point of view of the used radiation-shielding materials and their compositions was carried out. Experimental studies of the structure of paraffin radiation-shielding materials in the temperature range have been carried out in accordance with the requirements of regulatory and technical documentation. The features of the formation of homogeneous layers of neutron radiationshielding material are revealed.

A three-dimensional model of a portable container of a set of packing PKN-1A was developed and neutron irradiation of the container was simulated under conditions of transportation of a neutron source IBN-8-5. The equivalent dose rate values on the surface of containers with different composition of the radiation-shield material were calculated. Mathematical modeling and experimental studies of attenuation of the equivalent dose of neutron radiation from isotopic sources of fast neutrons on samples of materials of various compositions have been carried out. The results of mathematical modeling are in good agreement with experimental data.

Various criteria are analyzed for making optimal decisions on the composition of paraffin radiation protective materials and the features of the technology for working with them. The optimal solutions for this device of radiation technology can be rec- 
ommended for practical use in the manufacture of protective containers and devices. Based on the research results, a patent of Ukraine for a utility model was obtained [5].

\section{ACKNOWLEDGEMENT}

Special thanks to Ostrovskih V.E. for the provided experimental results, as well as valuable advice and comments when working on this article.

\section{References}

1. X-5 Monte Carlo Team. MCNP - A General Monte Carlo N-Particle Transport Code, Version 5. Volume I: Overview and Theory. LA-UR03-1987, Los Alamos National Laboratory, Los Alamos, N.M., 2003.

2. ATOMBUDPROEKT. Kiev Engineering Technology Center, Limited Li- ability Company (ABP KETS,LLC) https://youcontrol.com.ua/en/catalog/ company_details/33227452/

3. V.G. Rudychev, I.O. Girka, Y.V. Rudychev, et al. Change of radioactive waste characteristics at their processing and storage at nuclear power plants // Problems of Atomic Science and Technology. Series "Nuclear Physics Investigations". 2015, N3(97), p.8388.

4. ICRU Report 10b: Physical Aspects of Irradiation (NBS Handbook 85), 1964.

5. Ye.V.Rudychev, H.V.Sapyelkina. Prystriy radiatsiyno-okhoronnyy pakuvalnyy dlya transportuvannya radioizotopnykh dzherel shvydkykh neytroniv: Patent na korysnu model(Patent of Ukraine for utility model) N 107486, Derzhavnyy reyestr patentiv Ukrayiny na korysni modeli (State Register of Patents of Ukraine for utility models), Byul.N11, 10.06.2016.

\title{
ИССЛЕДОВАНИЕ ФИЗИЧЕСКИХ ПРОЦЕССОВ И ОПТИМИЗАЦИЯ СОСТАВА РАДИАЦИОННО-ЗАЩИТНОГО СЛОЯ ИЗДЕЛИЯ ПКН-1А
}

\author{
Е.В. Рудычев, С.И. Прохореи, М.А. Хажммурадов
}

Работа посвящена анализу особенностей транспортировки изотопных источников быстрых нейтронов с точки зрения применяемых радиационно-защитных материалов и их составов. Разработана трехмерная модель переносного контейнера комплекта упаковочного ПКН-1А, и проведено моделирование нейтронного облучения контейнера в условиях транспортировки нейтронного источника ИБН-8-5. Рассчитаны значения МЭД на поверхности контейнеров с различным составом защитного материала. Проведены экспериментальные исследования ослабления эквивалентной дозы нейтронного излучения от изотопных источников быстрых нейтронов для образцов материала различного состава. Результаты математического моделирования хорошо согласуются с экспериментальными данными.

\section{ДОСЛІДЖЕННЯ ФІЗИЧНИХ ПРОЦЕСІВ ТА ОПТИМІЗАЦІЯ СКЛАДУ РАДІАЦИЙО-ЗАХИСНОГО ШАРУ ВИРОБУ ПКН-1А

\author{
Є.В. Рудичев, С.I. Прохорець, М.А. Хажмурадов
}

Робота присвячена аналізу особливостей транспортування ізотопних джерел швидких нейтронів з точки зору застосовуваних радіаційно-захисних матеріалів та їх складу. Розроблено тривимірну модель переносного контейнера комплекту пакувального ПКН-1А, і проведено моделювання нейтронного опромінення контейнера в умовах транспортування нейтронного джерела ІБН-8-5. Розраховані значення ПЕД на поверхні контейнерів з різним складом захисного матеріалу. Проведено експериментальні дослідження ослаблення еквівалентної дози нейтронного випромінювання від ізотопних джерел швидких нейтронів для зразків матеріалу різного складу. Результати математичного моделювання добре узгоджуються з експериментальними даними. 